\title{
Dansa i moralitat medieval en Francesc Eiximenis: Lo Libre de les Dones
}

\section{Dance and medieval morality in Francesc Eiximenis: Lo Libre de les Dones}

\author{
Xavier Dalmau Martínez \\ xavidalmau@outlook.com \\ Universitat de València
}

\begin{abstract}
Resum: En aquest estudi revisem les citacions a la dansa que apareixen a Lo Libre de les Dones de Francesc Eiximenis. Es tracta d'una anàlisi basada en la descripció i en l'exemplificació tot per a perfilar la moral medieval catalana des d'un punt de trobada entre el ball i la moralitat, dividint les citacions entre danses bones (les danses a Déu, als àngels i les danses en paradís) i les danses dolentes (danses del pecat i la luxúria, i danses contra moral). Així analitzem el binomi dansaliteratura per a entendre les societats anteriors, els rituals, els pensaments i tradicions antigues que han sigut transportades en el temps amb el folklore, la cultura tradicional i amb l'Església i que formen part de la nostra riquesa cultural i de la nostra identitat com a poble.
\end{abstract}

Paraules clau: dansa, ball, moralitat medieval, Edat Mitjana, Francesc Eiximenis.

Abstract: In this study we revise the quotations on dance that appear in Lo Libre de les Dones by Francesc Eiximenis. This is a description-based analysis and exemplification to outline medieval Catalan morality from a point of convergence between dance and morality, dividing the quotations into good dances (dances to God, to the angels and dances in paradise) and the wicked dances (dances of sin and luxury, and dances against morality). This is how we analyse the dance-literature binomial to understand previous societies, rituals, thoughts, and ancient traditions that have been transported through time with folklore, traditional culture and the Church, and which form part of our cultural wealth and our identity as people.

Keywords: dance, medieval morality, Middle Ages, Francesc Eiximenis. 


\section{Introducció}

Lo libre de les dones és un manuscrit que el framenor Francesc Eiximenis va dedicar a les dones i que tracta $\mathrm{i}$ analitza els comportaments que les dones havien de seguir a l'època, fent referència a moralistes coetanis però també a tractadistes, escriptors... tot per a perfilar la condició femenina. Ara bé, encara que comença posant el focus en les dones anirà canviant-lo a poc a poc a la moral medieval a l'estil de Lo Crestià, amb un caràcter més generalista.

Podem destacar que el llibre està dedicat a difondre l'exemplaritat religiosa dins del col lectiu de les dones de l'Església, i tot amb el temor que la mala conducta es poguera estendre. Ara bé, cal remarcar que tot i que aquest llibre està dedicat a les dones - de fet amb una menció especial a la comtessa de Prades Sança Ximenis d'Arenós-, no deixa de ser-ne per a un públic majoritàriament masculí, ja que la major part dels lectors eren homes (Vinyoles \& Comas 2002). No obstant això, podem partir del fet que l'educació de les dones en la cort havia caigut en decadència amb el declivi de la societat de la "fin'amors" (Cantavella 1988), i no és d'estranyar que els moralistes -que s'havien encarregat de l'educació dels joves de les capes benestants de la societat anteriorment- tingueren la voluntat de marcar el "camí correcte" o inclús marcar els oficis de la dona i les tasques que havia de saber dur a terme.

Francesc Eiximenis en el panorama catalanòfon no sembla ser dels més misògins. De fet, ja al llibre Lo Crestià (Eiximenis 1929; 1994) defensava el paper de la prostituta medieval i "valorava" el seu treball per a la societat $i$ el dret a viure dels guanys que aquest treball ocasionava, tot i ser pecat'. Aquesta visió també s'aprecia en Lo llibre de les dones. Per contra, molts coetanis del gironí no eren partidaris del respecte de la dona -era una creació de Déu-, i s'oposaven al fet que les dones saberen de lletres -llegir, escriure i raonar-. Amb tot, del que es fugia era de dotar a la dona d'una ferramenta com era l'escriptura que donava cabuda a que elles escrigueren cartes que trencaven l'aillament femení dins de la casa, i a més tindre enamorats. Eiximenis es mostra així contrari a la tendència de l'època (Cantavella 1988).

El framenor demostra la seua posició de laxitud, ja que com explica, el fet de saber llegir i escriure no vol dir que puga secretejar més, i considera més perilloses les paraules i els gestos que pot intercanviar amb l'amant. Així podem comprovar que el llenguatge corporal, les senyes i la llengua eren de gran importància en un món majoritàriament analfabet, però que gaudia d'un llenguatge corporal extens amb diversos objectius. En aquest sentit, la dansa -femenina, majoritàriament- en les seues distintes manifestacions i la seua aprovació o reprovació, adquireix un paper fonamental que ens ajudarà, sens dubte, a conèixer millor la moralitat de l'època medieval.

Les referències a la dansa en Lo libre de les dones són recurrents durant tota l'obra i normalment van lligades als mals exemples de conducta. Així, nosaltres les analitzem des de la moralitat medieval como a una ferramenta clau de comunicació no verbal, i trobem onze esments a la dansa al llarg del manuscrit amb diferents modalitats dancístiques. Aquestes les classifiquem en danses bones 
-dividides en danses a Déu, danses dels àngels i danses al paradís- i les danses dolentes -dividides en danses del pecat i la luxúria, i danses contra moral- per a una millor comprensió. Tot un ventall d'expressions amb l'objectiu de donar visibilitat a les arts escèniques i connectar el binomi dansaliteratura poc analitzat pels investigadors, per a contextualitzar l'Edat Mitjana amb la dansa i crear una connexió entre la moralitat medieval i la història de la dansa en els moralistes, ja que està estretament relacionada amb els codis de conducta, amb la feminitat $\mathrm{i}$ amb el cos de la dona medieval.

\section{La dansa en perspectiva}

Al llarg del tota l'obra ens trobem amb un sac de mots dispars i d'ortografia canviant que fan referència explícita a la dansa o ball durant els dos volums de l'obra (Eiximenis 1981: vol. 1 i 2). Alhora, posem en relleu que les paraules que apareixen per a anomenar la dansa són aquestes: baylls, bayll, dançant, dançar. balant, balles, balar, ballar, balls. També hem detectat en algun cas l'aparició d'homògrafs que tendeixen a la confusió quan es parla de balls i baix on de vegades es representa amb la mateixa grafia baylls.

Des de l'inici fins al final de l'obra podem fer una distinció simple però clara de les referències explícites. Encara que podem trobar referències que no són específicament dansaires però que també es poden connectar amb la dansa de diverses maneres. Aquestes estan relacionades amb moviments, reverències, vestimentes, conductes o fins i tot els cinc sentits. Les bones, és a dir, aquelles referències en què es tracta la dansa com a una cosa d'origen i caràcter beneficiós, honorable, angelical o celestial. Aquesta és la dansa dedicada a Déu, als àngels -o dels àngels- i a la Mare de Déu, que conformen danses de joia i devoció als éssers celestials. En contraposició trobem les dolentes, aquelles que deixen entreveure un caràcter perjudicial per a l'ànima i la moralitat medieval de l'època, amb una visió pejorativa i recriminadora que fan palesa de la voluntat d'extirpar aquest costum. Aquesta és la més extensa i és, a més, la dansa relacionada amb el pecat, el vici, les fembres vils e sutzes o fembres pecadrius, les relacionades amb el dimoni, amb la dona i el seu cos en general i amb la luxúria en particular

Tot i que la distinció entre les danses bones i les danses dolentes és nostra, aquesta està estretament relacionada amb la Bíblia. La diferenciació és clau per a entendre la dansa medieval des de la perspectiva actual, així com la seua iconografia. Com a representació de la dansa bona en la Bíblia tenim el cas del rei David, autor dels salms i que Eiximenis anomena constantment. Aquest és, curiosament, el referent bíblic d'aquesta dansa "bona" que en essència està dedicada a Déu. La dansa de David es narra així: «quan torna l'arca de Déu de l'aliança a Jerusalem, David realitza un ball que a ulls de la seua dona Micol és més propi d'un histrió que no pas d'un rei» (Kovács 2014: 124), aquesta referència apareix al segon llibre de Samuel $(6,1-23)$ i és mostra del tipus de ball humil i devot que es realitza en honor i per enaltir la figura del déu cristià: «David i tots els israelites 
dansaven davant el Senyor acompanyats de fusta savina, arpes, cítares, tamborins, sistres i címbals» segon llibre de Samuel (6, 5-6) (La Bíblia, bíblia catalana : traducció interconfessional 1994). Aquests tipus de danses simbolitzen l'agraïment i la humilitat davant Déu (Kovács 2014: 123) i de fet ja en fa menció el menoret sobre la dansa de David a Lo Crestià, concretament al capítol DCXVII.

D’altra banda, la figura bíblica de Salomé representa l'altra cara de la moneda, el ball que no s'havia de realitzar, aquell més impur i mal vist. Una dansa que segons sembla seria de caràcter eròtic, més relacionada amb la luxúria i les pecadrius, i que a més seria responsable de la decapitació de Joan Baptista al Nou Testament. Tanmateix, el caràcter sexualitzat de la dansa de Salomé no està realment clar, ja que basant-nos en les il lustracions medievals la xiqueta podria estar realitzant acrobàcies i posicions normals per a la dansa de l'època (Markessinis 1995: 19-20). Trobem aquesta cita a Marc (6, 21-28): «(...) Durant el convit entrà la filla d’Herodies a ballar, i va agradar tant a Herodes $i$ als convidats, que el rei li digué a la noia: -Demana'm el que vulguis i t'ho donaré», $i$ aquesta incitada per la seua mare, demana el cap de Joan Baptista, cosa que semblaria ser un càstig diví per la realització d'aquesta dansa "sensual". També es dona constància del mateix fet a Mateu $(14,6-12)$ arran de la mort de Joan Baptista. Així aquesta distinció de danses bones i dolentes està estretament inspirada en aquests dos fets bíblics.

Centrant-nos ara en Lo libre de les dones, les referències explícites a l'art dansaire són exactament onze, dividides en quatre bones i set dolentes, deixant clar que es critica més la dansa que no pas es venera. Les cites transcorren durant tot el recorregut de la lectura basada en els dos volums. Així ara les tractarem una per una començant per les danses bones, i acabant amb les danses dolentes.

\section{Les danses bones}

Com ja s'ha avançat, les danses bones són les que tenen relació amb Déu o amb algun element divinal o litúrgic, la devoció, el culte, la humilitat i la postració al diví, aquests són els elements que marquen els balls. Una característica remarcable és el sentiment de joia i felicitat del que gaudeixen els dansaires que les realitzen, felicitat que ve provocada pel déu celestial i que irradia com un raig del sol. També està estretament relacionada la intenció a l'hora d'entendre aquestes danses, perquè, tot i ser danses, la intenció pura i neta dels qui la realitzen lleva de tota espurna de pecat que puga contenir.

El cas de la dona de David, en el passatge bíblic, n’és un bon exemple. Micol veu a David ballant alegrement en honor a Déu, però ella cegada per les connotacions tradicionals del ball que radicaven en la seua societat veu amb ulls maliciosos aquest esdeveniment. Mostra d'açò és el que ella li diu: aquest ball és més propi d'un histrió que no pas d'un rei. Tanmateix aquest comentari li costarà la seua fertilitat per sempre. 


\section{Danses a Déu}

Les danses a Déu són la primera classificació que podem trobar a Lo libre de les dones. Així, només hem trobat una citació d'aquest tipus i es troba ben bé al principi de l'obra quan parla de les donzelles i de la importància de la virginitat i la castedat que aquestes han de portar. Les danses a Déu, així com la dansa bíblica de David, són unes danses dedicades a la divinitat que són realitzades per la devoció i la felicitat que aporta el déu celestial als fidels. Aquestes danses solen anar relacionades amb la grupalitat, és a dir, solen ser danses col lectives i compartides, una mena d'èxtasi produïda per aquest sentiment diví.

Segons Lenke Kovács, el ball medieval es pot classificar en tres tipus depenent els qui conformen la dansa: ball individual, ball en parella o ball col lectiu. Els balls individuals anirien lligats a alguns personatges destacats de la història (Kovács 2014: 123), encara que des de la nostra perspectiva, la dansa de David, encara que tinga un nom individual, no fou una realització individual sinó ben bé col lectiva, ja que a l'escena diu així: «David i tots els israelites dansaven davant el Senyor (...)» segon llibre de Samuel (6, 5-6). Amb el benentés que David és el personatge important del passatge bíblic, no deixa de ser una dansa col lectiva de tots els israelites amb David, amb goig i reverència a Déu. Així doncs, nosaltres refutem aquesta teoria de dansa individual en aquest passatge deixant obert aquest debat.

El passatge de l'obra d'Eiximenis també fa menció a aquesta grupalitat. Al capítol XIX, on parla de la conducta exemplar de les donzelles i del temor a Déu que aquestes han de mostrar, cita la dansa com a un esdeveniment diví lligat a la condició de castedat i virginitat d'aquestes dones joves «E con en Paradís Jesucrist ensenya al poble virginal special amor, e ls vèrgens li fan special cant e bayll entorn: E con són ab los àngels pus acostats, axí con a germans, car diu ell: Àngel e virginitat germans són» (Eiximenis 1981: 37). Així veiem aquesta relació dels verges amb la trinitat, ja que la personificació de Jesucrist fill seu és la que està en contacte amb els verges tot i que ell és un amb Déu, així que entenem que les danses que es podien realitzar són en honor seu. Aquesta és l'única referència que trobem de fidels que ballen a divinitats, almenys fins a aquest punt de l'obra. Cal destacar que les danses dels àngels i les del paradís estan estretament relacionades, fins al punt que aquesta es podria considerar una d'elles pel fet que es compara els verges amb els àngels, tenen una relació estreta i agermanada, i d'altra, aquesta dansa es realitza en Paradís.

És interessant destacar que no sembla fer menció a cap dansa bona que no estiga en Paradís, fent una separació entre les danses que es realitzen en la terra i les danses que es realitzen al cel. Una explicació podria ser que la natura humana, molt tendent a pecar, no seria capaç de fer uns balls tan purs com els qui realitzen fidels i àngels a Paradís, encara que aquesta teòrica cau en comparar-la amb la del rei David que sí que es produeixen a la vida terrenal.

La figura del cercle és recurrent per a les danses bones i pures, fins i tot és anomenada en aquest passatge, ja que recalca la naturalesa del ball com a bayll entorn, entorn de Jesucrist, i per tant s'entén que la figura que realitzen és un cercle amb Jesús o fins i tot Déu, en mig. 


\section{Danses dels àngels}

Les danses dels àngels estan estretament relacionades amb les danses a Déu, ja que aquestes també se solen realitzar entorn de la figura de Déu o de Jesucrist. També, com s’ha esmentat, els àngels i les verges tenen una relació més agermanada que no pas la dels terrenals "corromputs" i altres classificacions dels éssers humans no tan pures, ho veiem amb aquesta frase del capítol XXX: «E virginitat és en lo cel pugada sobre los àngels» (Eiximenis 1981: 55). Fins i tot s'esmenta que les verges són lloades pels àngels, per la seua distinció i perquè Déu les honora porten una aurèola. Tanmateix, volem distingir aquestes dues, ja que els qui realitzen la dansa són diferents, uns no deixen de ser humans, i els altres són ens celestials.

Feta aquesta distinció, cal destacar que hi ha una dansa dels àngels citada a Lo libre de les dones. A l'esmentat capítol XXX que dedica a la dignitat de la virginitat que s'ha de protegir, fa al lusió a la trobada entre àngels $i$ verges. Els àngels contents per la castedat de les verges, les lloen i realitzen balls entorn de Jesucrist per venerar-les i honorar-les. Ball al qual s'afegeixen verges i el qui anomena l'Anyell, el mateix Jesucrist.

$\mathrm{E} \cdot \mathrm{ls}$ àngels los criden grans laors devant tothom, e fan un bayll davant Jesucrist, e dient-li un cant axí alt e preciós que negun altre no y és apellat ne 1 sap, sinó ells, ab l'Anyell. E en aquell cant e bayll e goig estan per tostemps ab Jesucrist. (Eiximenis 1981: 55)

Tots aquests ens purs es congreguen units i amb la voluntat de celebrar, però com veiem, el cercle està present en la realització de les danses. Encara que aquestes citacions fan esment de passatges celestials, les danses de l'església tenen tendència a repetir aquest tipus de representacions dansaires. És a dir, emmirallats en les danses celestials que duen a terme els àngels i els qui estan al cel, els qui estan en la terra representen aquestes danses amb un caràcter més terrenal, i òbviament menys pur, però simulant la puresa d'un acte tan grandiloqüent com el que es menciona al capítol XXX. No és casualitat que les danses esmentades al Llibre Vermell de Montserrat siguen a ball redó (Gómez Muntané 2000) -en cercle- així com les que realitzen els àngel.

\section{Les danses al paradís}

Dins d'aquesta distinció entre les danses bones, les danses al paradís són dues referències explícites a la dansa en què Eiximenis dedica un capítol sencer per a parlar dels balls i els cants que es realitzen. Amb tot, el framenor dibuixa una imatge utòpica del paradís on a poc a poc va donant informació de les condicions, de la vida i la festa d'aquest lloc on tot cristià aspira a arribar. Cal dir que aquests dos passatges són summament importants, ja que l'autor plasma amb un capítol independent i propi el significat de la dansa a escala celestial i religiosa. Nivell que es plasma a les danses eclesiàstiques, de l'església, que es podien realitzar al patí o fins i tot a l'altar. 
Aprés haurà aquí bals , e los bals seran no dissoluts, mas per excés de goig e de glòria, en laor del Senyor. E ls balls quells seran formats en diverses spècies de figures geomètricas. Car aquí haurà e ball lonch, e ball rodó, e ball triangular, e bal quadrat, e axí de les altres figures. E los bals aquels beneyts respondran als cants, e los cants als baylls. (Eiximenis 1981: 567)

Com veiem en aquest passatge es cita diverses vegades la paraula ball. S'està fent esment del tipus de ball que es troba al paradís. Primerament, ens diu que el ball és no dissolut, és a dir, remarca la característica d'un ball que és plenament pur i honest, i açò es deu al gran goig i la joia que dona l'encontre amb Déu per a lloar-lo infinitament. Així tenim el primer atribut d'aquestes danses. Segonament, parla de la formació d'aquests balls, els balls es realitzen amb figures geomètriques i les esmenta, aquestes són: la línia -ball lonch-, el cercle -ball rodó-, el triangle -ball triangular-, el quadrat -bal quadrat- $i$ altres figures que no exemplifica. La figura del cercle està present una vegada més i estreta la relació del cercle amb tot el que és celestial i diví. Així les figures han de ser perfectes amb angles simètrics tot simulant la perfecció de Déu, amb el cercle com a màxim representant d'aquest.

De fet, aquesta màxima del cercle, segons Francesc Massip basat en els estudis de Henri Rey-Flaud, és deguda a que és la disposició espontània del ser humà quan es combrega en grup, és a dir, el cercle, envoltar alguna cosa o algú. Així com també apareix des de tradicions ancestrals que res tenen en comú amb el cristianisme, però que veneren figures o persones de la mateixa manera. Així existeix aquesta tendència natural de l'ésser humà (Rey-Flaud 1973). Com a exemple, a Auxerre, França, hi ha una dansa eclesiàstica anomenada dansa de pilota. Aquesta dansa era una dansa de Pasqua en la qual intervenien els canonges de la catedral i es realitzava a la nau d'aquesta. El ball es combina amb els càntics de Victimae paschali laudes, amb l'orgue i llançant una pilota, de la qual rep el nom (Gougaud 1914: 235) i podria ser que en la realització d'aquestes danses es feren formacions circulars.

La primera filera de citacions al ball del capítol CCCXCI intitulat Qui ensenya con, en Paradís, ha cants e bals e jochs (on es troba ben explicitada la menció a Lactanci), és un bon exemple per a redescobrir el tipus de dansa acceptada per l'Església, com es conformava, i que partia de la intenció de representar aquests balls divinals al món terrenal, en honor a Déu, i evitant pecar amb una voluntat de llaor i amb la intenció més pura i honesta que eixia del goig i l'amor.

En aquest mateix capítol hi ha una menció una mica diferent del ball, ja que va lligada a l'Apocalipsi en boca de Lactanci, escriptor llatí nascut el $240 \mathrm{dC}$, i que tracta els balls que es realitzen en aquest esdeveniment: «Cant cantaran de leys, faran bals plans e drets, a dar a entendre que totes les leys divinals són planes e dretes e sens tota tortura, fundades en sobirana justícia e veritat» (Eiximenis 1981: 568). Així ens revela que el ball pot arribar a representar les lleis de divinals, els balls plans i drets -sense moviments brucs ni salts- simbolitzen el caràcter d'aquestes lleis regides pels mateixos atributs, creant una simbiosi entre dansa i teologia que és vertaderament màgica. 
La reverència apareix també al capítol d'una manera diferent: «Cant cantaran de juys, lavors tots se encorven e s baxen aval, a dar entendre que, qui tracta dels sobirans juys divinals, aquel los deu tractar ab sobirana humilitat e reverència, car aquí ha amagada infinita saviea (...)» (Eiximenis 1981: 568). Així, descriu el moviment de la postració, encorbar el cos i baixar-lo, postrant-se davant del Judici Final, reverenciant a Déu. Aquest moviment podríem connectar-lo amb l'actual plié de la dansa clàssica, que és una flexió dels genolls, sense pujar els talons, dirigint els genolls cap a fora en direccions oposades, formant un rombe entre les cames.

No obstant això, els moviments passen a ser elevats amb salts quan es tracta de representar l'amor a Déu: «Cant canten de amors, lavors tots salten e 's leven en alt a manera de flames de foch, a dar entendre que, tocats de aquella sobirana amor de Déu, són axí ardents e fervents e luens com lo foch (...)» (Eiximenis 1981: 568). Sembla que l'amor a la divinitat condueix a un èxtasi que recorda el nirvana budista, on s'esvaneixen les preocupacions sent un sentiment d'eufòria que evoca els moviments ràpids, els salts alts representant les flames del foc, mimetitzant l'amor que senten amb el moviment de les flames i la calor i la llum que desprenen. A continuació mostrem un dels últims paràgrafs del capítol que és de gran interés, on parla dels jocs que es realitzen al paradís i de la dansa que fan, de fet esmenta la figura dels sants amb danses que duran a terme:

\footnotetext{
Aprés hi ha jochs, car, con diu la Scriptura Santa, la saviea de Déu tostemps jugua davant Déu, ensenyant de si coses altes e meraveyloses. E açò ensenyen los sans en lurs bals, car una gran balla se pot fer dins un sant, sens tota lesura sua, e un tot sol pot ésser balant e saltant dins molts senes tota lesura sua. Axí metex un sant, volent glorificar Déu, en la sua espertesa saltarà de orient a ponent, e de migjorn a tramuntana; e axí, ensenyant los dons reebuts de Déu, farà actes alts e obres maraveyloses. (Eiximenis 1981: 568)
}

Aquests jocs que esmenta segueixen sent la realització d'algun tipus de representació en honor a Déu, enaltint-lo. La figura dels sants és ben rellevant en el passatge, ja que fins ara no havien tingut relació els sants i les danses. S'apel la al ball individual, lliure de lesions, amb salts i moviments grans perquè esmenta el fet que els sants no rebrien cap dany físic en realitzar-lo. Sempre amb la voluntat de glorificar i honorar a Déu. En aquest cas, la figura individual -el sant- és qui realitza l'acció, però els altres atributs són els mateixos, de fet, els salts d'orient a ponent i de migjorn a tramuntana són una forma de fer menció al ball lonch que s'ha esmentat amb anterioritat.

Acabem així la part dedicada a les danses bones que és fruit de la divergència d'opinions envers la dansa, de vegades venerada i conreada com és el cas, i de vegades punida i rebutjada pel món de l'Església. Francesc Eiximenis concep doncs la dansa bona com a nexe d'unió entre la divinitat, el paradís i el món terrenal, la manera de postrar-se a Déu i de celebrar la bonança que significa l'ascensió. Com esmenta Massip en boca de Leo Spitzer, la primera Església proclamava la dansa, imitant l'harmonia del món (Buttà et al. 2014: 66). A més, el món litúrgic cristià va crear diverses 
danses sagrades que representaven aquesta veneració, ballades pels eclesiàstics i fidels dins de l'església i ocasionalment en festivitat destacades -com el Corpus Christi-, també en les esglésies de peregrinació (Buttà et al. 2014: 66) -com és el cas del Llibre Vermell de Montserrat- que conformen aquest panorama de danses moralment correctes.

\section{Les danses dolentes}

Les danses dolentes són aquelles que tracten el punt de vista moral més estricte. Recollim set citacions de la dansa dolenta a Lo libre de les dones, convertint-se així en el gènere dansaire més blasmat i esmentat pels moralistes de l'època, ja que Francesc Eiximenis només és un de tants autors que veuen amb mals ulls aquesta pràctica. Així, reflecteixen la visió moralista envers la dansa, la visió que representava en la majoria dels casos la visió real que es tenia de la dansa. Aquesta era una visió que anava ben lligada al pecat i concretament amb la luxúria. Usar el cos en benefici propi no estava ben vist, i menys, la provocació que suposava usar-lo per a atraure els homes, els clients o per a aconseguir qualsevol cosa. La classificació que nosaltres proposem és una classificació simple que recull les set citacions i les divideix en dos grups: les danses pecaminoses i les danses moralment condemnables. Així parlem de danses del pecat i la luxúria, i danses contra moral.

\section{Danses del pecat i la luxúria}

Les referències de les danses pecaminoses que trobem al llibre són dues. Això no vol dir que les que es comenten a l'apartat seguidament posterior no compartisquen aquesta aura pecaminosa, sinó que ben bé hem graduat les referències, les explícitament pecat i les relacionades amb la conducta.

La primera citació es troba al segon volum, al capítol CCCXVIII intitulat Con de mundícia de cor bix vera contricció dels nostres peccats. Com bé diu el títol, explica com la natura humana afecta els pecats, $\mathrm{i}$ com a través de no deixar el cor lliure és controlable el pecat, fins al punt que el cor pot deslliurarnos del pecat si es reprimeix adequadament. Així doncs, trobem aquesta menció al ball genèric com a mal i com a pecat:

\footnotetext{
Huytenament, hi ajuda molt tribulació, car l'om tribulat tot se estreny, e a la fi, si bon hom és, a Déu se à girar; e Déu l'aurà e deliurar, e ell no pot haver Déu si doncs no li apparex davant tot net. Per tal deya Orígenes axí: O beneyta sia la tribulació!, car ella salva aquells que los delits porten fins en infern. Gran enamich de natura humana, diu aquest, és lo carnal o mundanal delit, car tapa l'uyll del cor a l'hom, e ab huyll tapat, dançant e balant, porta l'om a la forcha, di doncs tribulació no l'empara, qui li destap l'uyll e l'aport a Déu, a qui l f faça recórrer. (Eiximenis 1981: 463)
} 
Aquest passatge ens aporta una visió molt interessant d'aquest temor a Déu de la religió cristiana. La tribulació, que és una aflicció o una situació difícil, és un camí que recondueix a Déu. Com diu Eiximenis, aquesta tribulació fa que un home que vulga pecar s'acabe acostant a la divinitat provocat pel temor de les males tribulacions. Aquest és un reflex natural que evita que l'home cometa delits tals que els condueixen a l'infern.

A més, esmenta que quan es tapa l'ull del cor, l'home pot dansar i ballar, i açò el portarà a la forca. Veiem doncs la relació d'aquesta citació entre el ball com a element pecaminós que condueix al càstig divinal, a infern i a la mort. És una metàfora que reflecteix que si es fa sempre el que es vol, lliurement -ballar seria la representació de la llibertat del cos-, hi hauran després unes conseqüències molt negatives. Així en boca de l'escriptor de l'Església africana Orígenes, relaciona el ball amb la llibertat i la desmesura, anar cegat pel cor i aquest acte de ballar du la persona a la desgràcia. Podem recalcar que al passatge s'usa el genèric d'hom' per a parlar d'aquest fet. Així sembla que no atribueix el fet de ballar a les dones, com sí atribueix en altres passatges. Aquesta citació és neutral i busca plasmar aquesta llibertat del cos que representa la dansa, per a reflectir que l'autocorrecció i el temor a la inestabilitat són dos factors que allunyen la persona de pecar i d'aquest excés de llibertat que representa el ball a l'Edat Mitjana.

Quan ens acostem a la finalització de Lo libre de les dones hi ha una part dedicada a penedir-se dels pecats. Explica com s'ha de pregar, com s'ha de demanar perdó, i com i que s'ha de dir quan algun fidel ha pecat $i$ ha de confessar-se. Eiximenis exemplifica bastament amb diverses maneres de ferho, amb oracions ja pactades i amb una classificació dels pecats.

Endinsant-nos a la segona citació, el capítol CCCXXVIII exemplifica com hem de confessar-nos segons quins pecats hem comés. De fet, aquest capítol el dedica als pecats mortals, i com no, la luxúria n'és un dels set. El passatge diu així:

\footnotetext{
Setenament me confés a Déu e a vós de peccat de lutxúria. Açí digues com has haguts molts mals desigs e moltes males cogitacions e mals delits e mals consentiments. (...) Confessa't encara si (...) t'est adelitat en vils paraules o esguarts; si vas de nits e per què; si ab juglars e ab cantars; o as trameses alcavotes, e menades balles, o ballat; o cantades o fetes letres de carnals amors (Eiximenis 1981: 478-479).
}

Primerament, ens diu com hem de començar la confessió. La persona s'ha de confessar si ha pecat greument, ho veiem fins a la tercera línia del text. Tanmateix, encapçala l'altra part amb un «Confessa't encara si...», aquesta fórmula pot atribuir-se a la gradació dels pecats, primer s'han de confessar els pitjors desitjos i els mals i després inclús les accions que a primera vista no han semblat pecat però en definitiva ho són i per això el framenor ho recalca al text. 
Així doncs, el ball apareix lligat amb la nit, la prostitució, els joglars i els cants, que són en conclusió, les activitats de l'època que es trobaven en el punt de mira. Però a més, fa una distinció rellevant entre els tipus de danses. D’una banda esmenta les balles menades, és a dir, els balls dirigits per un mateix, que han nascut de la intenció del mateix pecador. D'altra banda trobem la referència a ballar, clar i senzill, i que es refereix a qualsevol altre tipus de dansa. Així ens topem amb una classificació relacionada amb la voluntat i dibuixa una línia entre els balls que l'individu du a terme, on incita i dirigeix els altres, o a ell mateix -ball individual-, i després aquells on això no és rellevant, ja que l'individu s'hi pot unir, incitat per altri, entenent-ho com a ball col lectiu.

\section{Danses contra moral}

Finalment, les últimes citacions que trobem són aquelles que tracten la dansa com a una pràctica amoral, mal vista i que s'ha d'evitar, tot i que no s'especifica que siga pecat mortal, com sí que és el cas dels dos fragments anteriors. Les referències d'aquest caire són cinc i conclouen així amb el nombre total d'esments a la dansa que conté el llibre. Les que hem anomenat danses contra moral són aquells fragments on s'esmenta la dansa o el ball explícitament, però que estan relacionats amb la conducta exemplar, i no pas com a danses pecaminoses. La voluntat i la conducta marquen aquestes citacions on el menoret menciona el que les dones no han de fer per a seguir una moral cristiana perfecta. Recordem que Lo libre de les dones és un llibre sobre dones per a homes -basant-nos en Teresa Vinyoles i Rosanna Cantavella-, que es basa en la moral cristiana de l'època, un manual de les bones ensenyances envers la figura femenina que capta l'atenció de rituals com els del ball.

Podem clarificar que la primera part del llibre la dedica a coses generals de la condició femenina, i després divideix les dones en els cinc grups següents: xiquetes -infantes-, donzelles, dones maridades, vídues i dones religioses. La primera referència al ball la trobem al primer volum al capítol XXIX intitulat Que la terça guarda de les dones e donzelles és que no sia enamoradissa, així solament amb el títol ja sabem que aquesta citació està relacionada amb les donzelles, aquelles dones que han passat la infantesa i que prompte estaran llestes per a ser maridades, i com ja diu, les donzelles no han de ser enamoradisses i esmenta diverses raons per les quals han de fugir de l'enamorament esporàdic.

En boca del poeta Aulus Gèl lius, Eiximenis enumera alguns actes i fets que la donzella ha d'evitar per a conservar el cor pur i net i ser honesta així com les xiquetes. Veiem com una d'aquestes coses a evitar és el ball:

(...) La donzella -la cursiva és nostra- deu haver l'uyll fort honest. Ne deu hoir neguna lega paraula, ne truffar volenter, ne parlar ab los hòmens, ne portar grans hodors axí con mosquet o algàlia e semblants, car qui 'n porta no dóna bon eximpli de si metexa, ne són odors honestes. Ne deu ésser massa volenterosa a ballar, ne a burlar, magorment llà hon hòmens aga (Eiximenis 1981: 53). 
En aquest passatge veiem doncs algunes coses essencials que hauria de complir una donzella medieval. No havia d'escoltar males paraules, ni burlar-se a voluntat, ni parlar amb els homes, ni tampoc posar-se perfums, i el que és més important: la donzella no havia de tindre voluntat de ballar. Això ho podem traslladar a què la dona tampoc havia de tindre la iniciativa, siga amb el ball o amb qualsevol altra cosa. El que és també destacable és que matisa que davant de la presència d'un o més homes seria pitjor i majorment reprovable.

Amb tot, aquesta citació ens aporta la matisació conductual de la dona que hauria d'evitar el ball i evitar també que li agradara la dansa en general, així podria complir amb els cànons d'Eiximenis i de molts altres moralistes. No és l'únic cas, ja que una mica més avançat el llibre, el framenor fa una crítica a les dones franceses que està relacionada amb la conducta, i també amb la dansa:

\begin{abstract}
(...) ascuns generosos de França vingueren ab lurs muyllers e ab totes ses cases en Nàpols. E con alscuns hòmens de paratge napoletans apreessen de anar a la manera d'aquells francesos, ço és, curts e strets e fort dissolutament, lavors les dones de cort e de la dita ciutat volgueren ressemblar a aquelles dones franceses qui y eren vengudes en anar corts estretes axí con elles, e ballar tot jorn, e beure per les carreres, e anant cavalcant axí com a hom, e a besar e abraçar los hòmens davant tothom tot jorn, e de cantar francès gargolegant axí con fan les dones generoses en França, e de parlar de amors, e de anemoramens, e de motegar-se ab jóvens a la lur manera. (Eiximenis 1981: 90)
\end{abstract}

Sembla que a Eiximenis li sembla reprovable aquesta conducta de la dona francesa, és una crítica directa i a més, segueix amb una preocupació creixent de què aquesta conducta es puga estendre. Així l'exemple que donen unes dones s'escampa com la pólvora. Si totes segueixen el cànon conductual no es crea cap conflicte, en canvi el problema apareix quan alguna dona escapa d'aquesta moral i dona mal exemple a les altres, exemple que podrien seguir i que és una de les màximes preocupacions del franciscà.

És destacable que a la voluntat de ballar tothora, s'hi sumen vestidures curtes, perfums, mals parlars, relacions amb joves... un seguit de costums francesos que des del principi Eiximenis els relaciona amb el vici, i correlativament, amb el pecat mortal de luxúria. Podríem dir que la dona francesa és un exemple de dona de cort pecaminosa, un excés de llibertat que no agrada gaire al nostre autor. Això no vol dir que a França estiguera ben vista aquesta conducta, estava més immersa culturalment parlant, però en cap cas representaria una conducta exemplar. De fet, el Concili d'Avinyó (1209) va prohibir el ball "obscé" quan s'hi feien representacions eclesiàstiques i les poesies i cançons d'amor quedaven prohibides (Markessinis 1995). Altres concilis com el d'Auxerre (VI), Châlons (VII) entre algunes ciutats franceses també tenien aquesta voluntat de forta censura que no va impedir que es realitzaren danses i balls per part dels dansaires i joglars, sinó que a més no es va erradicar a l'església (Urso 2013), cosa que xoca amb la tradició francesa de la qual parla Eiximenis i que s'estén en aquest cas a la cort de Nàpols. 
Un altre exemple de citació que trobem de la dansa està relacionada amb aquesta visió de les dones que tenia Francesc Eiximenis, ja que defensava l'alfabetització de la dona i tot i recriminar les prostitutes volia que visqueren i foren tractades dignament, i que l'home respectara la figura femenina en tot moment. Entretant, també comparava la llengua de la dona amb la cua d'una cabra -sempre en moviment, i que es pot relacionar amb la figura del diable- i la seua habilitat xarraire amb el so de les costelles -creació d’Eva- quan són totes juntes. Visió que vindria marcada perquè el cos de la dona era atribuit com a un dels problemes de l'Edat Mitjana que representava un obstacle per a representar l'ordre de la creació - l'ordre social (Urso 2013: 59). A més, la identitat femenina era una balança entre la figura d'Eva i de Maria, i aquesta polaritat es veu reflectida en moralistes com Eiximenis.

El capítol LXXXVI de Lo libre de les dones, intitulat Com hom de bé no s deu engelosirper no res, ne sens gran rahó trobem la següent referència a la dansa:

\footnotetext{
E veges que cavallers volen comunament les muylers alegres e riens, e acompanyans, largues, liberals, bé acuylens a tothom, no perdonant a res cant vénen hostes, mas que tot ne vaga a frau. Los ciotedans comunament han tot lo contrari, car volrien que lurs muyllers sien a tothom esquives e que s'amaguen a tota res; ne jamés no s fassen a finestres, ne sien en baylls ne en truffes ab negú (Eiximenis 1981: 133).
}

Així, com déiem, el menoret defén la figura d'un home que s'ha de comportar amb les dones. Si llegim el capítol sencer, ens n'adonem que l'actitud conciliadora està present en la manera de tractar els problemes. L'home, quan veu una actitud desagradable o que directament no agrada a aquest, hauria de dialogar-ho amb la dona demanant-li de bones maneres que fera cas de l'home i que es comportara com ell considerara. També si la dona té en consideració i estima a aquest en farà cas i l'assumpte no es tornarà a esmentar. Així s'espera de l'home una actitud cortés i bones maneres que ha de ser no consensuada sinó acatada per la dona.

La distinció que fa entre els cavallers i els ciutadans és, si més no, classificadora. D’una banda el cavaller que vol una dona complement, amb bona actitud, volenterosa a les afirmacions, i d'altra, els ciutadans vists com a homes rudes que volen una dona asocial per al "propi consum". La dona ha d'estudiar el seu marit, ha de saber com és per complaure'l de la millor manera possible. Tanmateix, si comparem la dona del cavaller "liberal" i la dona del ciutadà "reprimida" esclareix que la dona del ciutadà no haurà de ballar, pel simple fet que hi ha altres homes i pot incitar a l'adulteri. Així com s'han d'evitar les finestres, s'hauria d'evitar tota acció provocadora, una d'aquestes, la dansa grupal o dual. Açò no vol dir que les dones dels cavallers puguen ballar quan les plaga si no quan es requerisca. En resum, Eiximenis apel tla a l'enteniment, a la paraula, a esquivar la gelosia, però també apel la a un caràcter conciliador que ha d'afavorir íntegrament l'home. Veiem doncs les recomanacions i les classificacions que fa l'autor envers dones que es casen amb homes amb distintes necessitats.

Després d'aquestes citacions explícites a la dansa, no és fins a ben avançada l'obra on trobem de nou aquestes mencions al ball. Com ja s'ha esmentat, el final de l'obra és un repàs sobre la fe, les 
confessions, un llibret resum de catequesi. Així és com ens trobem la penúltima menció al ball, quan Eiximenis ensenya el lector com s'ha de confessar correctament el fidel. Ací esmenta la dansa com a una ocupació dolenta lligada al tercer manament: Santificaràs les festes en nom de Déu. Ho planteja com a una ocupació diferent d'anar a missa, raó per la qual no s'han celebrat les festes de diumenge. Ho veiem:

Terçament, me confés a Déu e a vós, pare, del terç manament, ço és que no he colt lo sant dicmenge ne les festes manades per la santa Esgleya axí com deguera”. Açí digues en quines occupacions t'est occupat, ne si t'est mès en jugar o en ballar, o en altres occupacions males (...) (Eiximenis 1981: 471).

Directament, el framenor afirma que el ball és una mala ocupació i a banda és un motiu de confessió. Així, quan s'ha de celebrar les festes en nom de Déu, a l'església, el fet de jugar, cantar o ballar era considerat motiu de confessió per aquest incompliment del tercer manament. No obstant això, el més rellevant és com connecta la dansa amb una mala ocupació i per tant com a una mala conducta com a bon fidel cristià. Si bé cal destacar que la mentalitat medieval que es mantenia sobre l'univers femení -generalment- i l'ambigüitat de tolerar i culpar la dansa, sobretot lligada a la prostitució, també afectava les actrius o ballarines de professió, ja que s'entenia amb certa presumpció que podien anar lligades al negoci pecaminós (Urso 2013) tot i que no totes les prostitutes feien servir el ball i els espectacles de caire eròtic per atraure clients, ja foren pagesos, ciutadans, nobles, clergues o joglars (Sanchis Francés, 2020: 302).

Acabem aquest viatge amb l'última citació de dansa dolenta conductual que trobem al capítol CCCXLVII intitulat Con [se] deu hom appareylar a orar. La singularitat d'aquest esment és que a més, afegeix un exemplum per a explicar al lector la importància de no cometre aquests fets. Al capítol explica com s'ha de pregar correctament, s'ha de fer en veu alta - de bocha-i al temple de Déu, ja que fa referència al lloc idoni. Quan parla de l'església com a lloc on orar, recalca que aquest lloc sant, la casa de Déu, no és lloc per a pecar mortalment i s'han d'evitar les activitats que no es facen en honor al rei celestial. Una d'aquestes coses, com veiem, és ballar:

\footnotetext{
Deya Epifanus, scrivent a sancta Paula, que com la sancta Esgleya sia casa a Déu deputada on sia santificat lo preciós cors de Jesucrist, per lo qual sien aquí multitut d'àngels a la sua reverència, e sia loch on se fa lo sacrifici tot jorn e s diu l'offici divinal, per tal se deu fort guardar cascú de fer ne de dir coses qui no sien a glòria e ha honor de nostre senyor Déu, axí com parlar, trufar, balar e coses semblants (Eiximenis 1981: 505).
}

Així doncs, ballar no es considera com a acte en honor a Déu i per tant, no s'ha de realitzar a l'església. Ho plasma així amb aquest exemplum: «E recompta lo dit sant en la dita epístola que, com en la seu de Alexandria balassen alscuns qui havien fetes noçes, que tots tornaren muts e contrets, 
e que jamés negun no 'n poch curar ne guarir per res» (Eiximenis 1981: 505). Encara que, com hem vist, açò està estretament relacionat amb la voluntat, ja que les danses bones, amb la voluntat d'honorar el déu cristià es consideren una activitat pura i per tant es poden realitzar a l'església i fins i tot al mateix Paradís.

A través d'aquest exemple en boca d'Epifani de Salamina, Eiximenis ens deixa ben clar que l'església no ha de ser lloc per a les danses, ja que tot i la joia que representa la unió entre dues persones, $\mathrm{i}$ tot i que pot donar a episodis de balls o cants, van ser castigats a la seu d'Alexandria per no ser actes adequats a l'espai de celebració. Amb tot, ho pagaren amb les seues cordes vocals i el seu moviment per sempre. Amb aquesta referència ens mostra una posició rígida davant la dansa que no deixa de mostrar aquesta ambigüitat evident en la realització de balls i danses. Depenent dels ulls que analitzen la pràctica es podria tractar d'un ball honorable o no, però el que està clar és que no s'hi pot traçar una línia perfectament delimitada entre les danses que es consideraven bones $i$ les danses que es consideraven dolentes, ja que era, si més no, una percepció personal. Així doncs, acabem aquest viatge per les danses que trobem a Lo libre de les dones amb aquesta classificació que pot servir per a ordenar les danses i donar una visió més completa de les referències a la dansa, de la moralitat que es troba en aquestes i ens apropa al pensament de Francesc Eiximenis, i en general al de la societat medieval catalana.

\section{Conclusions}

Aquest estudi dona visibilitat a les arts escèniques en un camp d'investigació alternatiu interdisciplinari entre la dansa i la literatura. Amb la nostra anàlisi hem comprovat que a la literatura catalana hi ha abundants citacions i referències a la dansa que són d'especial interés per a explorar la moralitat medieval a través del binomi dansa-literatura. Altrament, amb l'anàlisi de totes les citacions explícites a la dansa medieval que apareixen a Lo libre de les dones podem concloure que la literatura catalana en general, i la medieval en particular, està replena d'esments al ball de gran interès que ens ajuden a construir una panoràmica de la concepció de la dansa durant els segles, i que ens aporta la càrrega moral des de la qual podem analitzar la literatura i entendre el món. L'estudi, a més, deixa veure que la concepció de la dansa medieval era prou personal i que resulta dificultós traçar una línia entre el que es considerava apte i el que no es podia tolerar.

Amb tot, concloem que els nostres objectius han estat bastament aconseguits i desitgem que siga profitós i desperte l'interés dels investigadors a participar en l'estudi de la dansa com a part de la literatura. Aquesta fusió que barreja la cultura tradicional i la tradició literària és de gran interés per a analitzar les societats passades, per a apropar-nos a les societats anteriors i entendre rituals, pensaments i tradicions antigues que han sigut transportades en el temps amb el folklore, la cultura tradicional i amb l'Església, i que formen part de la nostra riquesa cultural i de la nostra identitat com a poble. 


\section{Bibliografia}

La Bíblia, bíblia catalana : traducció interconfessional. (1994). Associació Bíblica de Catalunya.

Buttà, L., Carruesco, J., Massip, F., \& Subías, E. (2014). Danses imaginades, danses relatades. Paradigmes iconogräfics del ball des de l'antiguitat clàssica fins a l'edat mitjana. Tarragona. Institut Català d'Arqueologia Clàssica (ICAC).

Cantavella, R. (1988). "Lectura i cultura de la dona a l'edat mitjana: opinions d'autors en català". Caplletra. Revista Internacional de Filologia (Vol. 0, Issue 3, pp. 113-122). https://doi.org/10.7203/ caplletra.3.7621

Eiximenis, F. (1929). Terç del crestia. Barcelona. Barcino.

Eiximenis, F. (1981). Lo libre de les dones (J. Coromines \& F. Naccarato (eds.)). Barcelona. Ed. Curial.

Eiximenis, F. (1994). Lo crestià : selecció (A. G. (Albert G. Hauf (ed.); 2a ed.). Barcelona. Edicions 62.

Gómez Muntané, M. del C. (2000). El Llibre vermell de Montserrat : cants i dances s.XIV : summary in English. Sant Cugat del Vallès. Els llibres de la Frontera.

Gougaud, L. (1914). La danse dans les églises. Louvain. Peeters.

Kovács, L.(2014). "La valoració del ball en textos morals, religiosos i literaris a l'antiga Corona d'Aragó", dins Buttà, L., Carruesco, J., Massip, F., \& Subías, E. (2014). Danses imaginades, danses relatades. Paradigmes iconogräfics del ball des de l'antiguitat clàssica fins a l'edat mitjana. Tarragona. Institut Català d'Arqueologia Clàssica (ICAC).

Markessinis, A. (1995). Historia de la danza desde sus orígenes (R. Hightower (Ed.)). Madrid. Librerías Deportivas Esteban Sanz.

Rey-Flaud, H. (1973). Le Cercle magique. París.

Sanchis Francés, R. (2020). "Connexions entre el ball i la prostitució en la tardor medieval: fembres pecadrius, reis arlots i çabies". SCRIPTA. Revista Internacional de Literatura $i$ Cultura Medieval $i$ Moderna, 16, 300. https://doi.org/10.7203/scripta.16.19232

Urso, C. (2013). Donne, danze e spettacoli nel medioevo. Boni ludi o instrumenta diaboli?, m. 12, 59-78. Università degli studi di Catania. https://doi.org/10.4420/unict-asdf.12.2013.3

Vinyoles, T., \& Comas, M. (2002). Lo libre de les dones. Universitat de Barcelona. https://aladi.diba. cat $/$ record $=\mathrm{b} 1110628 \sim \mathrm{S} 171 *$ cat\#.X58O3TO8Vbs.mendeley 